\title{
Hadrian P. \\ THE USE OF AUDIT AS A TOOL FOR STRATEGIC CONTROL OF MARKETING ACTIVITIES OF POLISH ENTERPRISES
}

Об’єктом дослідження є аудит маркетингу у системі маркетингового контролю. Маркетинговий аудит це один із інструментів, що використовується для оцінки та покращення використання маркетингу в корпоративній діяльності. Одними з найбільш проблемних питань є діапазон контролю, що здійснюється в рамках аудиту маркетингу, передбачувані у зв'язку з цим ризики (аж до відмови використання цього інструмента контролю) та шляхи іх мінімізащї.

Проведено огляд запропонованих в літературі конщепщій структур аудиту маркетингу (наративний аналіз). Визначено основні рекомендащї щодо впровадження аудиту в системі контролю управління підприємством. Вивчено важливість та рівень використання маркетингового аудиту підприємствами, що діють у Польщі (дескриптивний аналіз).

Отримані результати досліджень, проведені в різний час розвитку польської економіки, приводять до загального ствердження, що суб'єкти, які в ній діють ще не досягли рівня зрілості, який схиляв би іх до впорядкованої, структурованої контрольної діяльності на стратегічному рівні. Причини такого стану справ можна знайти:

- в орієнтацї більшості суб’єктів на досягнення поточного успіху;

- у відсутності обізнаності про готові рішення, що підтримують такий рівень управління (в тому числі контроль);

- у знаходженні ірраціональних підстав для такого упущення (вказуючи в першу чергу на обмеження фінансових, людських, матеріальних, інтелектуальних ресурсів);

- у страху впровадження нових контрольних процедур та досягнутих результатів такого контролю, які не завжди є позитивними.

Для підвищення рівня обізнаності про аудит маркетингу рекомендується розповсюджувати цей інструмент в літературі з області управління. Слід підкреслити можливість здійснення часткових аудитів, присвячених вибраним елементам маркетингової діяльності. У порівнянні з системним аудитом їх простіше виконувати, вони менш дорогі. У той же час вони дозволяють провести дуже ретельну оцінку правильності маркетингової діяльності підприємств, мінімізуючи ризик функиіонування на ринку.

Ключові слова: маркетинговий менеджмент, стратегічний маркетинговий контроль, маркетинговий аудит, структура аудиту, польські підприємства.

\section{Introduction}

The analysis of the conditions in which enterprises will conduct business in the future, allows the identification of factors from different areas (endo- and exogenous) that will significantly influence (determine) their market position. These result from natural economic and social development of the contemporary world. These include development of media techniques, development of science and technology, emergence of a new type of citizens with a global awareness, initiative and transformation abilities, new security and participation needs springing from international connections, relativist attitudes as a manifestation of openness to cultural differences. Companies wishing to enhance the effectiveness of their activities in the variable reality must subject their different areas of operation to control mechanisms to ensure that each of them is properly arranged and adjusted to these conditions. Marketing is one such area.

Relying on the traditional outlook on marketing where it is considered to be a functional area of management generating relevant input data for strategic planning, the following roles of marketing in the overall corporate strategy have been identified [1]:

1) identification and presentation of recommendations on future trends and opportunities beginning to take shape in the field of company's market activities;

2) identification and presentation of recommendations on new marketing opportunities;

3) assessment of the scope of marketing assets required to make the best of such opportunities;

4) definition and execution of marketing strategies in line with a company's strategic direction.

Marketing audit is one of the tools used to assess and improve the utilisation of marketing in corporate activities. Therefore, it is important to study the nature and scope of this marketing control tool as well as the level of its use in practice.

\section{The object of research and its technological audit}

The object of research is marketing audit understood as a strategic control tool. In this approach, the marketing 
audit means a data processing procedure aimed to generate and select the organization's strategic behavior related to the process of making marketing decisions. Its scope covers all aspects of corporate market activities, being part of the scope and utilization of the rating of the effectiveness and assessment of the perfection of marketing activities.

This view refers to the concept of the structure of strategic marketing control, which includes the following components: marketing effectiveness rating, marketing auditing, assessment of marketing perfection, and assessment of corporate social and ethical responsibility [2, 3]. The key task within the framework of such control activities involves adjustment of the company's strategy to changes in the external environment.

The marketing audit - in the course of assessing the effectiveness of the adopted marketing solutions [4] contributes to the effective identification (up-dating) of opportunities and threats as well as stimulates response to these variables in the context of the company's marketing strengths and weaknesses [5]. For further details related to the definitions, scope and objectives of marketing audits [6-8].

A strategic approach to the significance and function of marketing audits is clearly seen at the early stages of developing this concept in business practice and theory. The strategic aspect of the concept is discussed by many authors [9-11]. In the subsequent decades of research authors offer different definitions, adapting them to the needs of marketing practice [12, 13].

An assessment of the possible applications of the marketing audit understood as a strategic control tool (marketing planning process) implies that it can be viewed as a method for verifying marketing strategic decisions in three fundamental areas:

1) an appropriate method for building (selecting) a marketing strategy;

2) the company's accountability for adopting its marketing strategy;

3) an appropriate method for strategy implementation.

Therefore, marketing audits relate to the assessment of processes at all marketing management levels [14-16]:

- a strategic level - it aims to develop a strategy for adjusting company operations to changes in the environment, ensuring improvements in the quality of serving target markets and achievement of objectives as compared with competitors);

- a tactical level - it aims to create conditions for implementing adopted strategic solutions;

- an operational level - it aims to satisfy customer needs and, consequently, to generate profits resulting from the sale of the company's products or services.

Such characteristics and a broad view of the role and importance of the marketing audit caused fundamental discrepancies both in the area of theoretical considerations and in business practice. They concern three basic, in the author's opinion, logically connected problems:

1) alternative treatment of audit as a tool of control or analysis within the marketing management process, which radically changes its role;

2) a set of issues which should be covered by the scope of audit, which substantially change its structure;

3) perceiving utility of marketing audit by the enterprises which is apparent by the level of its use in practice.

\section{The aim and objectives of research}

The aim of research is verification of the level of practical use of marketing audit as a tool of strategic control in the process of business management.

To achieve this aim, it is necessary to complete the following objectives:

1. Present the essence of marketing audit as a tool of strategic control.

2. Analyze the various marketing audit structures as a factor determining the degree of its use.

3. Present the results of the research (own and external) and identify the actual degree of use of the marketing audit in Polish enterprises.

\section{Research of existing solutions of the problem}

Similarly to all corporate decisions and activities, a marketing understood as a component of the management process should be subject to control and assessment. If marketing management is considered to be a series (cycle) of overlapping subsequent phases of corporate functioning (analysis, planning, organization, motivating, implementation and control), the components of the control process should be present in all the particular phases. In particular, a marketing audit, following the structure of a feedback process, closes one cycle of management and opens a subsequent stage, being then transformed into the phase of analyses. In this approach a marketing audit is often seen as a component of the marketing analysis of the company's condition.

The position of a marketing audit at the initial stage of the management process determines its scope and objectives, stressing the importance of the analysis of the company's environment as a basis for the strategic planning of marketing and, consequently, marketing operational activities. This view is shared by authors, who regard a marketing audit to be the first stage of planning marketing activities including market analyses, market segmentation, an analysis of competition as well as the company's key competences and assumptions [17]. A slightly different structure of audits is presented in the second and altered edition - attention is given to the audits of markets and company resources (in the context of the marketing-mix composition) [18]. Similar views are held other authors in $[19,20]$, who advocate the idea of the so called economics of speed and claim that the speed of grasping changes in the environment determines taking the right decisions, increasing the likelihood of gaining competitive advantage (first-player advantage). They also believe that it necessitates looking ahead and anticipating the sense of the company's existence and its operations, including marketing activities [21]. It seems that accepting the idea that a marketing audit is placed at the beginning of the management process implies a radical change of its role and character - it is not aimed to verify earlier decisions and activities, but it determines the initial conditions for undertaking relevant activities. The views held by a number of authors who associate audits with the analytical phase should not be disregarded as they clearly identify a number of components to be investigated by auditors in $[15,18,19]$. Besides, some of the authors are not very consistent in their approach when they link audits to different phases without clearly defining their character. 
For example, in [22], an audit is treated as an analytical tool for assessing the company's marketing situation in the course of developing its marketing plan, on page 118 a marketing control strategic tool.

The author of this paper, without any reservations, supports the view that the scope of audits treated as the components of the strategic marketing control process should focus on what (and if) the company does in a given area of its activities, and not on the description of the status of undertaken activities. Such description should be subject to a different type of control, referred to as marketing effectiveness rating and it provides a basis for auditing activities) [23].

The approach adopted by an auditing entity to the idea of marketing should determine the scope of audits with respect to the assessment of marketing decisions. The description of different approaches can be referred to various issues and specific questions presented in literatures in connection with the scope of auditing in the context of corporate marketing (Table 1).
A view which is more commonly accepted and widely cited in literatures - both at a theoretical and practical level is the one proposed [25], who identifies seven research areas: macroenvironment (distant environment), microenvironment (the environment in which activities are carried out; immediate environment; competitive environment), a marketing strategy, the organization of marketing, marketing systems, marketing effectiveness (productivity, efficiency - different terms are used to identify this area of auditing), and specific marketing functions. The broadly defined research areas cover a wide spectrum of issues as well as more specific questions.

More detailed marketing audit programs are available which include much broader research areas presented as extensive lists of questions to be answered by auditing entities. One of these programs [26] undoubtedly, it is subjective in character, and its structure results from the fact the author focuses on industrial marketing. However, it includes a very interesting and extensive list of questions which give insights into particular areas of auditing.

Table 1

The author's proposals related to the scope of marketing audits

\begin{tabular}{|c|c|c|c|c|}
\hline \multicolumn{5}{|c|}{ Sources of research } \\
\hline [24] & [25] & [26] & [27] & [21] \\
\hline $\begin{array}{l}\text { 1. The process audio: } \\
\text { - marketing planning; } \\
\text { - the current drive and control; } \\
\text { - acquisition and processing } \\
\text { of information. } \\
\text { 2. The strategy audio: } \\
\text { - the mission of the company; } \\
\text { - strategic goals; } \\
\text { - key tasks. } \\
\text { 3. The marketing-mix audio: } \\
\text { - compliance with the basic } \\
\text { strategic line; } \\
\text { - coordination of marketing } \\
\text { instruments; } \\
\text { - the regularity of the } \\
\text { relationship behavior goal- } \\
\text { measure. } \\
\text { 4. The organization audio: } \\
\text { - staff identification with the } \\
\text { objectives of the marketing; } \\
\text { - compatibility organizatio- } \\
\text { nal forms with the tasks; } \\
\text { - the efficiency of coordina- } \\
\text { tion of the activities }\end{array}$ & $\begin{array}{l}\text { 1. Macro-environment: } \\
\text { - demographic; } \\
\text { - economic; } \\
\text { - natural (environmental); } \\
\text { - technological; } \\
\text { - political-legal; } \\
\text { - social-cultural. } \\
\text { 2. Task: } \\
\text { - environment; } \\
\text { - markets; } \\
\text { - customers; } \\
\text { - competitors; } \\
\text { - channels (distribution and } \\
\text { dealers); } \\
\text { - suppliers; } \\
\text { - facilitators and marketing } \\
\text { firms; } \\
\text { - publics. } \\
\text { 3. Marketing strategy audit: } \\
\text { - corporate mission; } \\
\text { - marketing objectives; } \\
\text { - strategy. } \\
\text { 4. Marketing organization } \\
\text { audit: } \\
\text { - formal structure; } \\
\text { - functional efficiency; } \\
\text { - interface efficiency. } \\
\text { 5. Marketing systems audit: } \\
\text { - marketing information } \\
\text { system; } \\
\text { - marketing-planning system; } \\
\text { - marketing control system; } \\
\text { - new-product development } \\
\text { system. } \\
\text { 6. Marketing productivity } \\
\text { audit: } \\
\text { - profitability analysis; } \\
\text { - cost-effectiveness analysis. } \\
\text { 7. Marketing function audits: } \\
\text { - products; } \\
\text { - price; } \\
\text { - distribution; } \\
\text { - sales force; } \\
\text { - advertising, sales promo- } \\
\text { tion, publicity }\end{array}$ & $\begin{array}{l}\text { 1. Marketing strategy and } \\
\text { planning. } \\
\text { 2. Product/service range. } \\
\text { 3. The service element in } \\
\text { marketing. } \\
\text { 4. Company performance. } \\
\text { 5. Export marketing. } \\
\text { 6. Marketing information: } \\
\text { system and use. } \\
\text { 7. Market size and structure. } \\
\text { 8. Future market. } \\
\text { 9. The sales force and its } \\
\text { management. } \\
\text { 10. Customer care and sup- } \\
\text { port staff's role in marketing. } \\
\text { 11. Cross-selling and inter- } \\
\text { nal marketing. } \\
\text { 12. The agency system. } \\
\text { 13. Non-personal promotion: } \\
\text { methods and media. } \\
\text { 14. The distributive system. } \\
\text { 15. The buying process. } \\
\text { 16. Analyzing lost business. } \\
\text { 17. Introducing new products/ } \\
\text { services. } \\
\text { 18. User industries. } \\
\text { 19. Key customer marketing. } \\
\text { 20. Competitive intelligence. } \\
\text { 21. Physical distribution and } \\
\text { packaging. } \\
\text { 22. Industry contacts. } \\
\text { 23. Pricing. } \\
\text { 24. Images and perceptions. } \\
\text { 25. Duality In marketing. } \\
\text { 26. Non-differentiated pro- } \\
\text { ducts and commodities. } \\
\text { 27. Service businesses. } \\
\text { 28. Product/service financial } \\
\text { information }\end{array}$ & $\begin{array}{l}\text { 1. Objectives and marketing } \\
\text { strategy. } \\
\text { 2. Environment (climate } \\
\text { change). } \\
\text { 3. Segmentation and selec- } \\
\text { tion of target market. } \\
\text { 4. Differentiation and } \\
\text { positioning. } \\
\text { 5. Price policy. } \\
\text { 6. Product management. } \\
\text { 7. Advertising management. } \\
\text { 8. Public relations. } \\
\text { 9. Sales promotion manage- } \\
\text { ment. } \\
\text { 10. Direct marketing. } \\
\text { 11. Customer relationship } \\
\text { management. } \\
\text { 12. Customer service excel- } \\
\text { lence. } \\
\text { 13. Integrated marketing } \\
\text { communications. } \\
\text { 14. Distribution management. } \\
\text { 15. Marketing to commer- } \\
\text { cial intermediaries. } \\
\text { 16. Development of new } \\
\text { products. } \\
\text { 17. Marketing information } \\
\text { system. } \\
\text { 18. Brands benchmarking. } \\
\text { 19. Sales management. } \\
\text { 20. Marketing results. } \\
\text { 21. Marketing organization }\end{array}$ & $\begin{array}{l}\text { 1. Defining corporate mis- } \\
\text { sion statements. } \\
\text { 2. Value audit. } \\
\text { 3. Economic environment audit. } \\
\text { 4. Business ecosystem audit. } \\
\text { 5. Competitor audit. } \\
\text { 6. End-user audit. } \\
\text { 7. Product positioning audit. } \\
\text { 8. Pricing strategy audit. } \\
\text { 9. Distribution strategy audit. } \\
\text { 10. Promotion strategy audit. } \\
\text { 11. Speed and timing audit }\end{array}$ \\
\hline
\end{tabular}


A similar detailed analysis is proposed by Copernicus, a consulting company, which identifies 21 general areas of marketing activities for auditing purposes [27]. A different approach to strategic audit areas is proposed [21]. They stress the significance of such issues as values, the company's digital technological environment and the speed of response.

The main contribution of theoretical considerations is that they define auditing components or checklists for its implementation. Using the question checklist, the audit not only provides information on the organization's marketing condition [28], but also provides practical guidance on the planning, implementation and value of the marketing audit [29, 30]. However, the approach based on control questions has imperfections: it can detect problems, but it does not provide solutions; due to the qualitative nature of checklists, there is little empirical confirmation of their suitability for the assessment of marketing performance and the enrichment of knowledge about measurement properties [31]. Finally, the approach based on the checklist was developed as a universal, normative tool, without taking into account the internal and external conditions of each company.

The suggested structure of marketing audit is related to the concept of a system-level audit which in turn reverts to a «horizontal audit». This approach postulates control over all marketing activity and defines three main guidelines:

- audits should be carried out at regular intervals unlike analyses which are applied in critical situations; - the assessment should include the basic model of marketing activity as well as the efficiency of operation within that model;

- it is prerequisite to apply a comprehensive assessment of all marketing activity elements rather than only those which apply to potential problems.

Nonetheless, implementation of such approach may prove very difficult in practice (absorbing, costly, a challenge to organize); hence, it is suggested to apply action-level audit which is a simpler procedure providing an in-depth analysis of a clearly defined part of marketing program of a company.

The publications quoted in this paper and plethora of others on marketing audit prove that there is high interest in this tool, which seems to be a proper instrument facilitating a strategic control of marketing activity [32-34]. Irrespective of the concept or the form of an audit, it is important to reach for this tool in line with the view that strategic control concludes each management process. It is to be expected that such approach will be directly reflected in the practice of marketing activities [35-37].

The dual character of the meaning of audit which is present in theoretical considerations, pertaining to marketing management process (analyses versus control) and disparities within the width and depth (regarding detail) of the issues under consideration can be perceived as a distortion of its identity (the essence of the construct). Such condition must make an impact on the perception of this tool (its image). This must significantly influence the use of audit by the entities to which it should be of service. On the final note, the practical use of marketing audit in the economic practice verifies clarity and utility of that marketing tool. Such verification was attempted through analysis of the behavior of enterprises operating on Polish market.

\section{Methods of research}

The main research problem considered in the publication is determination of the significance and level of use of marketing audit by enterprises operating in Poland. The main research hypotheses are as follows:

- H1: Business entities operating on Polish market perceive marketing audit as an important tool to control their strategic marketing activity.

- H2: Despite an explicit description of the meaning and character of the marketing audit (its subject matter, the scope and methodology) provided by marketing literature, it is very rarely used by the entities operating on the Polish market.

Having verified thus formulated research hypotheses, the author of this paper referred to the results of quantitative research of other scholars (in the research, repeated surveys were employed to gather source information) as well as his own, with the application of case studies method. Case studies included in-depth interviews with people responsible for marketing activity in companies. The author added his own reviews of the documentation on marketing control amongst a selected group of companies of various sizes, qualified as the most dynamically growing entities in Poland.

\section{Research results}

Following the geopolitical makeover in Poland (the beginning of the 1990s), the economy broke away from the centralized model and rapidly developed. Consequently, the companies operating on this market started to profess marketing orientation. The dynamics of marketing activities gave grounds for reflection and testing how much they were proper, efficient and effective. The ensuing research on the marketing control system focused on the tools gauging the results of marketing, including the marketing audit.

One research project was conducted by the team of scholars from the Institute of Marketing Management at the Academy of Economics in Wrocław (currently Wrocław University of Economics). The research with the assistance of Computer Assisted Telephone Interviewing (CATI) was conducted between 2006 and 2007 on a sample of 251 directors and the heads of marketing, sales or trade divisions. The selected companies were manufacturing entities operating on the consumer markets and each employing over 250 staff. Following the verification of the questionnaires, 231 interviews were used to analyze the results. The sample comprised all Poland, and the researchers, basing on the observation of the ways of interpreting the marketing audit, diagnosed quite a consistent view of the purpose and structure of the audit as a control tool, which allowed them to formulate several research hypotheses, including stating that a marketing audit is the key (if not basic) strategic control tool with a very high degree of dissemination [38].

The research results indicated that only approximately half of the companies covered by the project ( $48 \%$ ) considered the assessment of strategic directions of marketing activity as quite important (rank 1 on a 3 -point scale), and almost one third (29.9 \%) thought it was important (rank 2). Yet, even between those two groups, marketing audit was not a common tool for marketing control, as it was used by approximately $2 / 5$ of each $(41.8 \%$ and $42.6 \%$ respectively). Hence, marketing audit did not prove to be 
a popular tool even for those companies which attributed the top rank to this strategic control task. What it means is that, most likely, the companies applied other tools of marketing control within strategic control area. However, the analysis of strategic control functioning allowed noting that amongst the group of companies which admitted using marketing audit, the score was slightly higher than for those respondents who did not use it (still, the difference was not statistically significant).

In general terms, the obtained research results did not allow positive verification of most of the research assumptions, including the key role of marketing audit as a strategic control tool. Within 231 companies, only 89 (38.5\%) admitted using marketing audit. Such results did not indicate a high use of marketing audit as a strategic control tool, despite the fact that strategic control directions were perceived to be quite important. At the same time, a relatively low interest was shown in the elementary constituent parts of marketing audit.

The research conducted in 2011 was the follow up to the above described project. The research was conducted by using CATI process on the sample of 140 directors and the heads of marketing, sales or trade divisions of companies employing more than 50 staff. The research was nationwide [39].

The measurements made during interviews included the perception of significance of various tasks of marketing control and the tools (methods) of controlling. The former was based on three basic categories: the assessment of strategic directions (market opportunities), the assessment of plan implementation and the assessment of efficiency. In turn, perception of significance of control tools was based on Ph. Kotler's classification. The set of assessed control tools included the analysis of sales, the analysis of the market share, the analysis of costs (expenditure) customer satisfaction surveys, the analysis of profitability, the analysis of the efficiency of marketing activities and marketing audit. Marketing audit was the only strategic control tool included in the measurements. The perception of significance of the above tasks and tools was gauged on the scale 1-9.

The obtained results indicated that the operational control tools, especially most tools included in the annual plan control were considered to be most significant for the surveyed group of managers. Cost analysis and sales analysis scored highest (average score 7.64, standard deviation 1.78; average score 7.62, standard deviation 2.07 respectively). In turn, market share analysis, also related to the annual plan control, reached one of the lowest significance perception scores. Another high score among control tools was attributed to the profitability analysis. The only basic strategic control tool i. e. marketing audit scored the lowest (average score 5.55, standard deviation 2.70). Such low score undermines the very rationale for marketing control as it shows a low rank of problems related to the evaluation of marketing activities at the strategic level. It is only this level of control which allows to assess the level of adaption of operations to the changing environment as well as to make the necessary adjustments (corrections) to the operating patterns. Such low perception of the marketing audit translates directly into a low level of use of this tool by the surveyed companies. Regrettably the author of the publication did not provide detailed information on the number of the surveyed companies which used marketing audit as a marketing control tool.

A similar survey was conducted in 2007 on a group of 423 large (employing over 250 people) and medium-sized companies (employing more than 50 people to 250) of the Pomeranian Voivodeship [40]. The study was conducted using the survey method. 199 questionnaires filled in by the representatives of the surveyed companies were collected (98 large companies and 101 medium-sized companies). Almost $60 \%$ of medium-sized companies and $70 \%$ of large ones declared conducting strategic marketing control as part of their activities, most often in combination with operational control (55.4\% and $65.6 \%$ respectively). Such result indicates that the majority of audited entities perceived the importance of this type of control (about two-thirds). Entities that did not indicate the implementation of this level of control attributed it to the lack of adequate funds, excessive costs (both financial and organizational), or simply irrelevance of this level of assessment of their operations. At the same time, it was found that the applicable management decisions do not always correspond to adequate control activities. For example, among companies that declare the formulation of strategic plans are those which do not conduct strategic control (and vice versa).

Within the group of entities which declare the use of strategic marketing control (60 average-sized and 74 large companies), about a half of average-sized companies (51.7\%) and over two fifths of large companies (43.2\%) assert that they use marketing audit for that purpose (jointly with the efficiency ranking - both groups reach about $35 \%)$. Hence, only 31 average-sized companies (30.7\% of all surveyed average-sized companies) and 32 large ones (32.6\% of all surveyed large companies) admit the use of marketing audit as a strategic marketing control tool.

The obtained result seems to prove low popularity of that control tool, and the listed dates of launching audit for the first time indicate a negligible increase in the number of entities convinced about the benefits of audit (within 1995-2000 an increase of one or two companies, and in the following years a faster increase at 4-6 companies). The results of the survey also give grounds for certain anxiety; did the surveyed entities understand properly the concept of marketing audit as a strategic control tool. This doubt is further aggravated by the declared frequency of implemented audits. Almost $20 \%$ of large companies and a surprising $56 \%$ of average-sized companies declared making a very intensive use of audits; monthly (6.5\% of companies), quarterly (3.2\% of large companies and $40.6 \%$ (sic) of average-sized or half-annual $(9.7 \%$ and $15.6 \%$ respectively). Such frequency of control would suggest its operating (if not on-going) character. The reported real activities of the surveyed entities seem to suggest that the obtained results showing the use of marketing audit (in the proper understanding of this term) are over-optimistic and need a significant correction. Such uncertainties are a clear flaw of each research (especially quantitative research) based on the declarations of entities (or their representatives) included in the survey.

Successive research on assessing the condition of knowledge and skills in the use of business audit tools (including marketing audit) [41] was implemented in 2017, within the statutory research conducted by the team of the Institute of Management at Warsaw School of Eco- 
nomics [42]. The research was aimed at diagnosing the scale of application of business audit tools in managing small and medium companies in Poland. Empirical research included evaluation of prerequisites for launching audit and the barriers hampering its application. The study was conducted among a deliberately chosen research sample, including 200 small and medium-sized enterprises operating in Poland. The research was conducted using the telephone interview method (CATI) with the owners or managers of the surveyed enterprises. The results obtained during the research are definitely of a preliminary nature, however, they characterize in a way the problem of using the audit in the practice of managing Polish enterprises.

The authors of these studies treated the audit as a management tool, enabling the diagnosis and assessment of the current state of the company, as well as recommending the best possible solutions and improvements, in order to improve its competitive position on the market. During the research, many research questions related to such problems as the importance and tasks attributed to the marketing audit in management practice, the type and scope of use of tools in the marketing audit process, audit implementation barriers, or practical effects of its use (effectiveness).

Only 66 enterprises (33\%) declared using a marketing audit (including, $4 \%$ regularly). Also, this result does not indicate high prevalence of marketing audit. Not all companies treated the audit as a control tool; some used it at the analysis stage in the marketing management process. Some enterprises carried out audits independently $(17.5 \%$, including $3 \%$ regularly), while the remaining group (15.5\%, including $1 \%$ regularly) used outsourcing activities [43]. In the audit, the most common techniques and research methods used in the management and marketing literature (regarding six areas of audit highlighted e. g. in [23]). The most important barriers to using the marketing audit were indicated by the lack of appropriate tools, human and financial resources, lack of time to implement such systematic (structured) research and difficulties in estimating its direct benefits (usability, increase of competitiveness, improvement of marketing efficiency). In his response to the above formulated doubts about the research, the author of this paper decided to make a quantitative research. He used the in-depth personal interview method, discussing the issues with the key executives of marketing divisions and direct review the documents on marketing control. Such approach allows an unequivocal verification of activities that were really undertaken within the researched entities. The companies were chosen by random selection on the basis of a ranking list of most dynamically developing entities operating on the Polish market. All the entities included in the research ranked in the top ten, separately for each region of Poland. The entities enjoyed the status of either large or average size companies, both in terms of manpower as well as the financial result. The research comprised the timeframe 2016-2017.

Over a dozen of companies which agreed to be included in the research voiced their concerns about the practice of marketing audit. A predominant majority of entities asked for their contribution to the research either did not agree to respond to in-depth questions or blatantly ignored it (about 60 companies were invited to participate in the research). This is a real problem in making scientific research as there is a clear contrast in the expectations of the economic practice which continually calls for supporting it with all kinds of results of analyses. By far, the managers responsible for the area of marketing stressed the necessity of providing marketing control at each level of management. However, they were not able to suggest any solutions or present the results of analysis and audits, particularly those of a strategic dimension. They indicated some general results of the control of marketing activities that appeared in the reports, presentations prepared for the needs of meetings of the Management Boards, Supervisory Boards or documents required by law (e. g. companies listed on the stock exchange). However, they were unable to present any material source (control report, inspection report) that would make these results credible. In many cases persistent questioning led to the final conclusion on the absence of auditing activity within the area of marketing. The arguments explaining such situation included:

- the lack of implementation of marketing activity;

- no need for conducting such activity on the part of the entity's owner;

- the lack of appropriate tools, competent human resources, financing resources, and time;

- sound financial standing of a company which does not necessitate analyzing the areas of its activity («sales are rising, no need to worry»);

- sufficient scope of current and operating controlling activity which guarantees proper operation in the area.

Only one company out of a dozen included in the survey, presented a full, realistic picture (documentation) of the auditing activity. In this company, marketing audit is conducted by an appointed Internal Audit unit. The successive audits are executed on recommendation of the members of the Board or the Supervisory Board who share their doubts. Within the set of over a hundred audits executed in that company from 2006 to 2016, a dozen pertain to the marketing area. The audits are carried out by auditor teams appointed for each case, consisting of at least two employees of the Internal Audit Department, at least one representative of the marketing unit responsible for the scope of audited activities, at least one mid-level or high-level managerial staff, not directly related with the studied area of activities. These were typical vertical audits which focused on clearly defined, very specific problems of marketing. The presented documentation allows following the whole procedure, methodology or the results of the conducted audits, including the results of auditors' recommendations.

The research results conducted at various times of development of the Polish economy lead to a general conclusion that the entities operating on Polish market have not yet reached such level of maturity which would induce them to undertake orderly, structured control activities at the strategic level. The reasons for this state of affairs can be found in:

- focusing by most entities on reaching current success (instead of a long-term orientation, looking to the future and consequently taking a broader perspective of the conducted activity);

- the lack of awareness about the ready solutions facilitating such level of management, including control (the available literature, mostly foreign, does not seem to be sufficient in this situation. This indicates the need for a stronger message to be formulated not just by the professional literature, but also a more 
efficient popular/scientific message reaching the economic practice;

- finding irrational grounds for such neglect (pointing in the first place to the insufficient sources of funding, limited human resources, inadequate intellectual potential). It is true that such shortcomings are persistent (the only thing we can do is to alleviate their acuteness) while the art of management predominantly consists in overcoming them. The other reason may be attributed to a peculiar vision of freedom; you do not have to do it (the law does not enforce it) hence it is not done;

- fear of implementing new control procedures and the potential results of such control, which are not necessarily positive. Regrettably, there is a pejorative perception of control as a supervision tool and the impending potential sanctions.

\section{SWOT analysis of research results}

Strengths. One of the strengths of a marking audit is its contribution to improving marketing orientation of enterprises. In its application of a strategic control tool, audit shows whether the conducted activities are consistent with marketing orientation and it verifies the appropriateness of the applied marketing strategies. By that token it mitigates the risk of bad practices. In comparison to other control tools, marketing audit seems to be the most complex system of assessment. The results of the presented surveys of Polish enterprises indicate quite a common perception of the audit as one of the possible marketing control tools (unfortunately not always assigned to the strategic level).

Weaknesses. The analysis showed that the scope of control proved to be a limiting factor of marketing audit application. Consequently, there are some organizational and economic issues which are involved in the effectiveness of its implementation. That weakness may be eradicated with the implementation of problem audits (with a narrow scope) that need less resources and effort. The results of surveys of Polish enterprises indicate that marketing audit is not a commonly used tool of marketing control, even among companies declaring the importance of strategic marketing control. It was also diagnosed with weak interest and orientation of enterprises in the areas that should (may) be subject to control as part of the marketing audit.

Opportunities. It should be noted that the systematic implementation of problem (partial) audits, dedicated to the next issues of marketing is a solution that allows a comprehensive look at the company's marketing. The sum of the obtained scores will allow for the final verification of the correctness of the marketing implementation of the enterprises' orientation. Analysis of the practice of marketing audit in Polish enterprises allows perceiving the chances of its application by including it in a wider category of strategic control, for which «internal audit» and «business audit» can be considered. In the future, the indication as part of a functional approach to these marketing audits as one of the key areas of business operations may be a factor strengthening (or even enforcing) the need to implement them. An additional supporting factor seems to be the growing offer of external research entities, supporting enterprises in the audit implementation (outsourcing)
Threats. The most important threats seem to be the lack of a clear, uniform, practical concept (structure) of conducting marketing audits and the lack of awareness among Polish entrepreneurs of the need to conduct marketing control activities. Regardless of the indicated reasons, not recognizing such a need, in the conditions of dynamically changing market environment of enterprises, seems to be a significant threat to their functioning. Thus, it is a significant threat to the functioning of the entire Polish economy.

\section{Conclusions}

1. The views in the scientific literature, which define the marketing audit as a tool that can be used in the control phase or the analysis phase of the management process, are given. Treating the audit as part of the control phase seems more appropriate. In this approach, all the features of the strategic nature of the audit are exposed.

2. The analysis of audit structures in its broad sense (system-level audits) makes the viewer aware of the diversity of views regarding significant marketing problems. Regardless of the number of element structures specified in particular concepts, they cover a very wide range of issues. This indicates that the audit is treated as a comprehensive control tool. At the same time, it becomes an important factor limiting its practical use (due to various difficulties related to the implementation of such extensive control).

3. The presented results of the research (conducted by the author as well other researchers) allow formulating a few conclusions, the most important of which refer to the research hypotheses. Neither the hypothesis about perceiving the crucial importance of audit as a tool of strategic marketing control, nor the hypothesis about an extensive use of this tool in the economic practice have been verified (negative verification). Entities operating on Polish market have not yet reached such level of maturity which would induce them to undertake orderly, structured control activities at the strategic level.

\section{References}

1. Globalizacja. Strategia i zarządzanie / Stonehouse G. et. al. Warszawa: Felberg SJA, 2001. 200 p.

2. Kotler Ph. Marketing. Analiza, planowanie, wdrażanie i kontrola. Warszawa: Gebethner i S-ka, 1994. P. 683, 694-703.

3. Kotler Ph. Marketing. Warszawa: Rebis, 2005. P. 711-717.

4. Strzyżewska M., Roszkiewicz M. Analizy marketingowe. Warszawa: Difin, 2002. 17 p.

5. Kowal W. Funkcjonowanie kontroli marketingowej w polskich przedsiębiorstwach // Marketing i Rynek. 2013. Issue 12. P. 17-23.

6. Hadrian P. Zmiany zakresu znaczeniowego pojęcia audyt marketingowy // Innowacje w Marketingu. Mlodzi o Marketingu III. Wydzial Ekonomiczny. Sopot: Uniwersytet Gdanski, 2005. P. $205-219$

7. Dryl W. Audyt marketingowy. Warszawa: CeDeWu, 2010 . P. $131-140$.

8. Kowal W. Kontrola skutecznosci marketingowej - problem zmiennosci interpretacji i pomiaru. Wroclaw: Wyd. Uniwersytetu Ekonomicznego, 2010. P. 144-155.

9. Shuchman A. The marketing audit: Its nature, purposes and problems / ed. by Newgarden A., Bailey E. R. // Analyzing and Improving Marketing Performance. «Marketing Audits» In Theory and Practice. Report No 32. New York: American Management Associations, 1959. P. 11-19.

10. Oxenfeldt, A. Executive Action in Marketing. Belmont: Wadsworth Publishing, 1966

11. Kotler Ph. Marketing Management. Analysis, Planning, Implementation and Control. New York: Englewood Cliffs. PrenticeHall Inc., 1976 
12. Mokwa M. P. The Strategic Marketing Audit: An Adoption/ Utilization Perspective // Journal of Business Strategy. 1986 Vol. 6, Issue 4. P. 88-95. doi: http://doi.org/10.1108/eb039136

13. Wilson M. The Management of Marketing. Westmead: Gowe Publishing, 1980

14. Cravens D. W. Strategic marketing. New York: Irwin, 1991. 65 p.

15. Penc-Pietrzak I. Strategiczne zarządzanie marketingiem. Warszawa: Wyd. Key Text, 1999. P. 18-20, 217-226.

16. Lambin J.-J. Strategiczne zarządzanie marketingowe. Warszawa: Wyd. Nauk. PWN, 2001. P. 25-31.

17. Piercy N. Market - Led Strategic Change. Oxford: ButterworthHeinemann, 1983. 118 p.

18. Piercy N. Marketing. Strategiczna reorientacja firmy. Warszawa: Felberg SJA, 2003. P. 230-234.

19. McDonald M. H. B., Wilson H. Marketing Plans: haw to prepare them; how to use them. Chichester: John Wiley \& Sons Ltd., 2011. Ch. 4. 573 p

20. Baker M. The strategic marketing plan Audit. A detailed top management Review of Every aspect of your company's marketing strategy. Axminster: Cambridge Strategy Publications Ltd., 2010.

21. Tvede L., Ohnemus P. Marketing strategies for the New Economy. Chichester: John Wiley \& Sons Ltd., 2001. P. 107-182.

22. Principles of marketing / Kotler Ph. et. al. London: Prentice Hall Europe, 1999. P. 111-112, 118

23. Kotler Ph., Keller K. L. Marketing. Poznań: Dom Wydawniczy REBIS, 2014. P. 694-695.

24. Köhler R. Marketing-Controlling: Konzepte und Methoden / ed. by Reinecke S., Tomczak T. // Handbuch Marketingcontrolling: Marketing als Motor von Wachstum und Erfolg. Frankfurt - Wien: Gabler, 2006. P. 39-61. doi: http://doi.org/ 10.1007/978-3-8349-9335-9_2

25. Wilson R. M. S., Giligan C. Strategic marketing management. Planning, implementation \& control. Oxford, Boston: Elsevier Butterworth-Heinemann on behalf of the Chartered Institute of Marketing, 2005.

26. Wilson A. The marketing audit handbook. Tools, techniques \& checklists to exploit your marketing resources. London: Kogan Page, 2002. 306 p.

27. Kotler P. Kotler o marketingu. Jak tworzyć, zdobywać i dominować na rynkach. Gliwice: Wyd. Helion / Onepress. 2010. P. 291-313.

28. Da Gama A. P. Marketing audits: The forgotten side of management? // Journal of Targeting, Measurement and Analysis for Marketing. 2012. Vol. 20, Issue 3-4. P. 212-222. doi: http:// doi.org/10.1057/jt.2012.17

29. Brownlie D. The conduct of marketing audits: A critical review and commentary // Industrial Marketing Management. 1996. Vol. 25, Issue 1. P. 11-22. doi: http://doi.org/10.1016/ 0019-8501(95)00036-4

30. Mylonakis J. Functions and responsibilities of marketing auditors in measuring organisational performance // International
Journal of Technology Management. 2003. Vol. 25, Issue 8. P. 814-825. doi: http://doi.org/10.1504/ijtm.2003.003139

31. Morgan N. A., Clark B. H., Gooner R. Marketing productivity, marketing audits, and systems for marketing performance assessment: integrating multiple perspectives // Journal of Business Research. 2002. Vol. 55, Issue 5. P. 363-375. doi: http://doi.org/ 10.1016/s0148-2963(00)00162-4

32. Loya A. Marketing audit - an important tool to determine strengths and weaknesses of the companies excel // International Journal of Multidisciplinary Management Studies. 2011. Vol. 1, Issue 2. P. 92-108

33. Radulescu V., Cetina I. Customer Analysis, Defining Component of Marketing Audit // Procedia - Social and Behaviora Sciences. 2012. Vol. 62. P. 308-312. doi: http://doi.org/10.1016/ j.sbspro.2012.09.050

34. Pankova S. V., Pasechnikova L. V. Sushhnost' audita marketinga i protsedury ego provedeniya // Mezhdunarodnyy bukhgalterskiy uchet. 2013. Vol. 16, Issue 7 (253). P. 22-30

35. Lipnicka D., Dado J. Marketing Audit and Factors Influencing Its Use in Practice of Companies (From an Expert Point of View) // Journal of Competitiveness. 2013. Vol. 5, Issue 4. P. 26-42. doi: http://doi.org/10.7441/joc.2013.04.02

36. Korobov O. V. Marketingovyy audit na predpriyatiyakh izdatel'skoy otrasli: puti modernizatsii // Ekonomicheskiy analiz: teoriya i praktika. 2010. Vol. 9, Issue 28. P. 59-64.

37. Tyurin D. V. Marketingovyy audit v rossiyskikh kompaniyakh: vidy, formy i metody provedeniya // Menedzhment segodnya. 2012. Issue 1 (67). P. 36-50.

38. Kowal W. Marketing audit as an instrument of marketing control: empirical research of Polish enterprises // Management sciences. 2011. Issue 9. P. 107-130.

39. Kowal W. System kontroli marketingowej w świetle wyników badań polskich przedsiębiorstw // Marketing i rynek. 2013. Issue 3. P. 17-24.

40. Dryl W. Audyt marketingowy. Warszawa: CeDeWu, 2010. 228 p.

41. Bulyga R. P., Mel'nik M. Audit biznesa. Praktika i problemy razvitiya. Moscow: Yuniti-Dana, 2013. 263 p.

42. Bachnik K. Audyt marketingowy w małych i średnich przedsiębiorstwach / ed. by Skowronek-Mielczarek A. // Audyt biznesowy w działalności małych i średnich przedsiębiorstw. Warszawa: Oficyna Wydawnicza - SGH Szkoła Główna Handlowa w Warszawie, 2018. P. 109-138.

43. Hadrian P. Outsourcing audytu marketingowego // Handel wewnętrzny. 2013. Vol. 1. P. 121-126.

Hadrian Piotr, Doctor of Economic Sciences, Senior Lecturer, Department of Marketing, Cracow University of Economics, Poland, e-mail: hadrianp@uek.krakow.pl, ORCID: http://orcid.org/00000003-0922-920X 